\title{
THE EFFECTS OF WELDING PARAMETERS ON BUTT JOINTS USING ROBOTIC GAS METAL ARC WELDING
}

\author{
A. A. Nuraini ${ }^{1, \mathrm{a}}$, A. S. Zainal ${ }^{1,2}$ and M. A. Azmah Hanim ${ }^{1, \mathrm{~b}}$ \\ ${ }^{1}$ Department of Mechanical and Manufacturing Engineering, \\ Faculty of Engineering, Universiti Putra Malaysia, \\ 43400 Serdang, Selangor, Malaysia \\ Phone : +603-8946-4382; Fax : +603-8656-7122 \\ ${ }^{a}$ Email: nuraini@eng.upm.edu.my \\ ${ }^{2}$ UniKL-Malaysia France Institute, Fabrication \& Joining Department, \\ Section 14, Jalan Teras Jernang, \\ 43650 Bandar Baru Bangi, Selangor, Malaysia
}

\begin{abstract}
Robotic gas metal arc welding (GMAW) is one of the most popular welding methods in the manufacturing industries. The main focus of this paper is how welding parameters affect the joining process. The butt joint will be used in this study to identify suitable welding parameters for welding voltage, welding current and welding speed. The experiment involves using a specimen of low carbon steel A1008 as base metal and AWS ER 70S-6 as the filler metal in the butt joint process. The joint was tested to determine the tensile strength, which is identified as the main characteristic of the weld, and the hardness of the weld is also recorded. The results show that a welding voltage of 24 volts, current of 200- 220 ampere, and speed of $45-50 \mathrm{~cm} / \mathrm{min}$ gave the highest tensile hardness of 239.05 MPa (180HV).
\end{abstract}

Keywords: Robotic gas metal arc welding; butt joint; low carbon steel; tensile strength.

\section{INTRODUCTION}

In today's manufacturing scenario, it is essential to have good quality welding to obtain a high quality product. In the field of welding, weld quality depends mainly on welding type, welding parameters, and the mechanical properties of the weld metal and heat affected zone (HAZ), which in turn is influenced by the metallurgical characteristics and chemical compositions of the weld (Charde, 2012a, 2012b, 2013; Kukiełka, 1989; Shah, Akhtar, \& Ishak, 2013). Gas metal arc welding (GMAW) is a welding process which joins metals by heating them to their melting point with an electric arc (LopezJuarez, Rios-Cabrera, \& Davila-Rios, 2010; Rafiqul, Ishak, \& Rahman, 2012; Rahman, Arrifin, Nor, \& Abdullah, 2008; Rahman, Bakar, Noor, Rejab, \& Sani, 2008; Rahman, Rosli, Noor, Sani, \& Julie, 2009). According to Yang \& Tarng (1989), GMAW is an adaptable process that can be used to weld a wide range of metals including carbon steels, low alloy steels, stainless steels, aluminum alloys, magnesium, copper and copper alloys, and nickel alloys. It can also be used to weld sheet metal and relatively heavy sections, and the process may be used for semiautomatic welding or automatic welding using a robotic application, as in this study.

Most industries nowadays use robotic welding equipment for the joining process, particularly the automotive industries. The robotic welding process has more advantages than the conventional manual process, such as that the quality of weld is 
more consistent, the process speed is higher compared with manual, there is less waste and a reduced cost. Although robot welding is very popular, welding parameter adjustment must be done manually. The correct parameters are important to ensure the precision of the robot and the quality of welding for the butt joint.

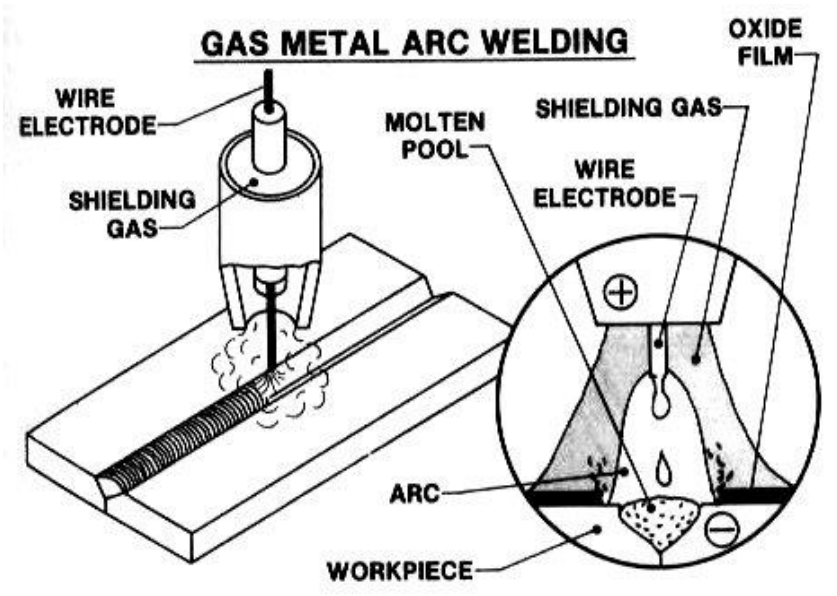

Figure 1. Gas metal arc welding (Yang \& Tarng, 1989)

Welding process parameters such as welding speed, welding current, shielding gas flow rate and gap distance play an important role in determining the mechanical properties of the weld, such as tensile load (Greyjevo \& Metodo, 2009). This is because butt joints are sensitive to weld defects where all forces on the joint are absorbed by the weld; defects such as porosity, distortion, cracks, etc., can easily cause the joint to fail catastrophically. In this study, low carbon steel was used as the base metal for butt joints using robotic GMAW. The effect of the welding process parameters on the weld properties in terms of tensile strength and maximum hardness value of the weld will be investigated in order to identify appropriate parameters for the welding process.

\section{EXPERIMENTAL WORKS}

Materials and Sample: A low carbon steel A1008 base metal plate of dimensions 200 x 120 x $6 \mathrm{~mm}$ has been prepared according to AWS D1.1/1 standard (American Welding Society, 2004) as shown in Figures 2(a) and (b). The process selected was the squaregroove weld, and the joint designation using B-L1b-GF, as shown in Figure 3. Specimens for the tensile test were taken from the middle of the joint and were cut using a laser cutting machine where the dimensions were according to the ASTM E8 standard, as shown in Figure. 4. The mechanical properties and composition percentages of the work piece material are listed in Table 1 and Table 2.

Table 1. Mechanical properties of base plate material.

\begin{tabular}{cccc}
\hline $\begin{array}{c}\text { Yield Strength } \\
(\mathrm{MPa})\end{array}$ & $\begin{array}{c}\text { Tensile Strength } \\
(\mathrm{MPa})\end{array}$ & $\begin{array}{c}\text { Elongation } \\
(\mathrm{mm})\end{array}$ & $\begin{array}{c}\text { Vickers Hardness } \\
(\mathrm{HV})\end{array}$ \\
\hline 167.17 & 224.62 & 25.04 & 147 \\
\hline
\end{tabular}




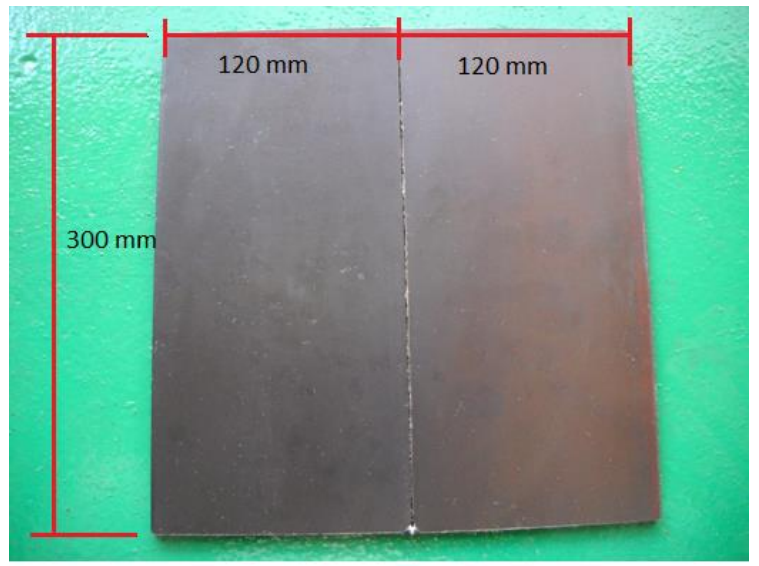

(a) Actual base plate sample

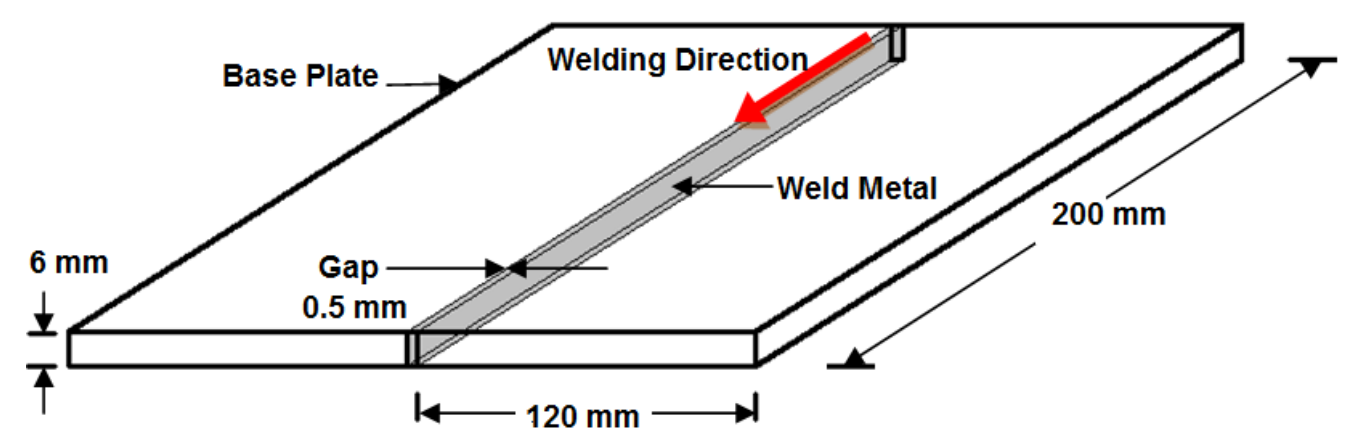

(b) Schematic diagram of the welding test plate

Figure 2. Welding base plate (American Welding Society, 2004)

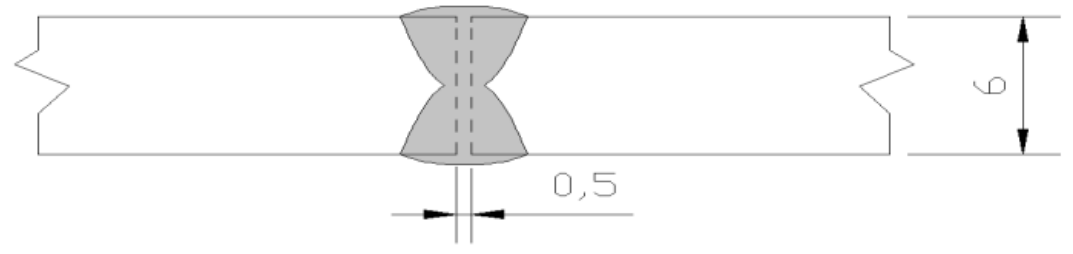

Figure 3. Side view of square groove weld (unit $\mathrm{mm}$ ) (American Welding Society, 2004)
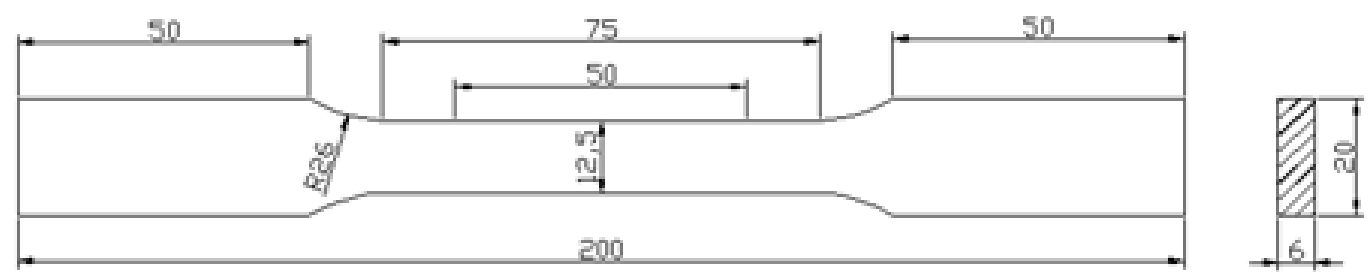

Figure 4. Configuration of a plan view tensile test specimen (unit $\mathrm{mm}$ ) (American Society for Testing and Materials) 
Table 2. Chemical composition of base material and filler material (American Welding Society, 2004).

\begin{tabular}{ccccccc}
\hline \multicolumn{7}{c}{ Chemical Composition (wt/\%) } \\
\hline & $\mathrm{C}$ & $\mathrm{Mn}$ & $\mathrm{S}$ & $\mathrm{P}$ & $\mathrm{Si}$ & $\mathrm{Cu}$ \\
Base Metal & 0.103 & 0.140 & 0.002 & $<0.0005$ & 0.025 & 0.160 \\
Filler Metal & 0.11 & 1.15 & 0.012 & 0.011 & 0.53 & 0.5 \\
AWS ER 70S-6 & & & & & & \\
\hline
\end{tabular}

Experiment Procedures: There were two types of experiments involved in this research. First the base plate was welded according to the directions shown in Figure 2(b), using the GMAW process with a robotics controller using OTC Digital Converter Model DP400 (Figure 5). The welding process parameters for GWAW, as stated in Table 3, and the design of the experiments (DOE) was adapted for a total of nine (Manning) tests for every different level and the process parameters as shown in Table 4.

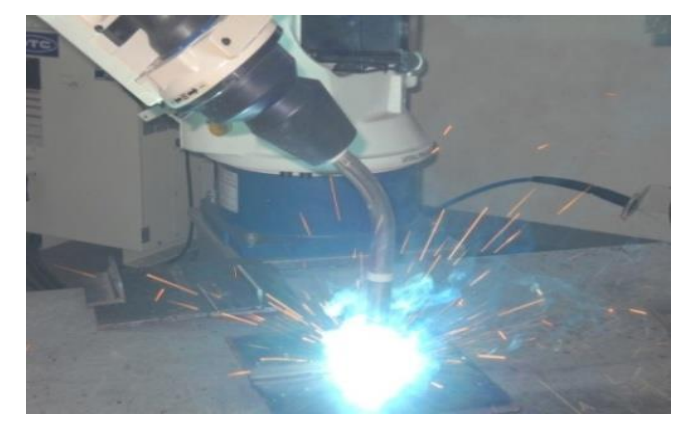

Figure 5. Robotic GMAW.

Table 3. GMAW process parameters.

\begin{tabular}{|c|c|c|c|c|c|}
\hline \multirow[t]{2}{*}{ Process Parameter } & \multirow[b]{2}{*}{ Notation } & \multirow[b]{2}{*}{ Units } & \multicolumn{3}{|c|}{ Level } \\
\hline & & & $\begin{array}{c}\text { Lower } \\
\text { level } \\
(1)\end{array}$ & $\begin{array}{c}\text { Medium } \\
\text { Level } \\
\text { (2) }\end{array}$ & $\begin{array}{c}\text { Upper } \\
\text { Level } \\
(3)\end{array}$ \\
\hline Current & $\mathrm{A}$ & (Amp) & 180 & 200 & 220 \\
\hline Voltage & V & (Volt) & 24 & 25 & 26 \\
\hline Travel Speed & S & $(\mathrm{cm} / \mathrm{min})$ & 40 & 45 & 50 \\
\hline
\end{tabular}

Each test used three (3) samples in order to determine the tensile strength using the tensile testing machine (make: Hung Ta -500T). Hardness tests were determined at the middle of the joints. Micro-hardness tests were carried out on the welded samples at the weldment area (Figure 6) with a load of 300 grams and a duration of 15 seconds using a Vickers digital micro-hardness tester (make: Yata, model: HT-9502). 
The effects of welding parameters on butt joints using robotic gas metal arc welding

Table 4. No. of tests at different parameters and levels

\begin{tabular}{cccc}
\hline Test No & Ampere & Voltage & Travel Speed \\
\hline 1 & A1 & V1 & S1 \\
2 & A1 & V2 & S2 \\
3 & A1 & V3 & S3 \\
4 & A2 & V1 & S2 \\
5 & A2 & V2 & S3 \\
6 & A2 & V3 & S1 \\
7 & A3 & V1 & S3 \\
8 & A3 & V2 & S1 \\
9 & A3 & V3 & S2 \\
\hline
\end{tabular}

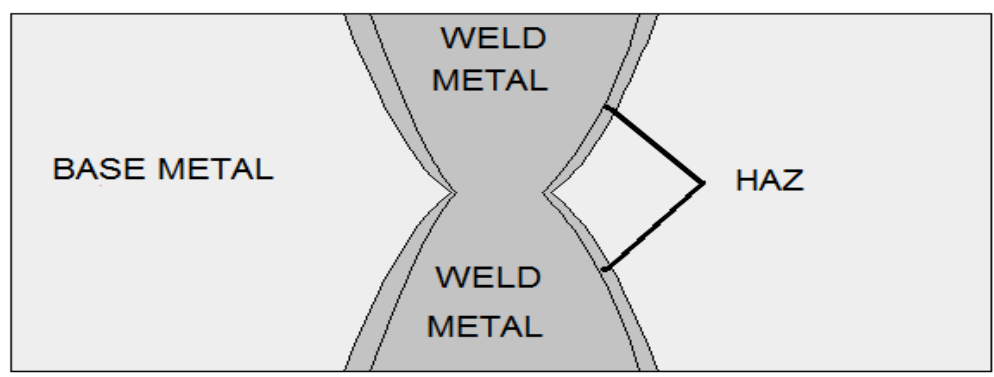

Figure 6. Weldment area of the joint

\section{RESULTS AND DISCUSSION}

This section will discuss the experimental results of the welding process. All welded specimens failed at the base metal region, and the properties related to the base metal are obtained but not the weld metal. The data for tensile tests in Table 5 and Table 6 shows results for tensile strength and hardness of the sample respectively. The maximum tensile strength of $239.05 \mathrm{MPa}$ was determined from Test 4 and the minimum tensile strength was $212.85 \mathrm{MPa}$ from Test 9 . The hardness results for the weld, as in Table 6, shows that the maximum value occurred in Tests 7 and 9 while the minimum value occurred in Test 6 .

For the maximum tensile strength results, the process parameters were at A2, $\mathrm{V} 1, \mathrm{~S} 2$ in Test 4, and the reading for the hardness test shows the maximum value occurs in two different tests at A3, V1, S3 and A3, V3, S2 for Tests 7 and 9 respectively. The process parameters for maximum hardness in Test 9 show a minimum reading for tensile strength which was not part of the criteria. This shows that the process parameters for Tests 4 and 7 can be considered an appropriate set for the welding process. The lower level of voltage and the ampere should be between medium and upper levels, because this will affect the heat affected zone of the weld area, especially during the solidification process between the filler and base metal. The travelling speed of the robotic arms also needs to be in the range between $45-50 \mathrm{~cm} / \mathrm{min}$ in order to ensure the filler metal covered the weld area of the joint. 
Table 5. Results for the tensile tests.

\begin{tabular}{ccccc}
\hline \multirow{2}{*}{$\begin{array}{l}\text { Test } \\
\text { No. }\end{array}$} & \multicolumn{4}{c}{ Tensile Test (MPa) } \\
\cline { 2 - 5 } & Sample 1 & Sample 2 & Sample 3 & Average \\
\hline 1 & 228.83 & 221.93 & 233.61 & 228.12 \\
2 & 225.48 & 239.98 & 196.41 & 220.62 \\
3 & 238.92 & 214.21 & 228.71 & 227.28 \\
4 & 240.35 & 235.81 & 241.00 & 239.05 \\
5 & 241.94 & 234.14 & 196.04 & 224.04 \\
6 & 243.20 & 233.08 & 169.30 & 215.19 \\
7 & 235.53 & 235.32 & 222.62 & 231.16 \\
8 & 237.90 & 240.10 & 236.92 & 238.31 \\
9 & 238.83 & 158.35 & 241.37 & 212.85 \\
\hline
\end{tabular}

Table 6. Results for hardness.

\begin{tabular}{ccccc}
\hline Test & \multicolumn{4}{c}{ Hardness (HV) } \\
\cline { 2 - 5 } No. & Sample 1 & Sample 2 & Sample 3 & Average \\
\hline 1 & 180 & 168 & 181 & 176.3 \\
2 & 160 & 169 & 185 & 171.3 \\
3 & 163 & 179 & 170 & 170.7 \\
4 & 170 & 175 & 168 & 171.0 \\
5 & 173 & 177 & 165 & 171.7 \\
6 & 167 & 160 & 158 & 158.3 \\
7 & 199 & 182 & 161 & 180.7 \\
8 & 190 & 167 & 180 & 179.0 \\
9 & 164 & 189 & 189 & 180.7 \\
\hline
\end{tabular}

\section{CONCLUSIONS}

The results obtained for tensile strength and hardness show that different levels of ampere, voltage and travel speed in the welding process affect the maximum and minimum values of the weld properties. The study determines that the process parameters to obtain maximum values for the weld properties are between 200-220 amp for the current, 24 volts for the voltage and $45-50 \mathrm{~cm} / \mathrm{min}$ for travel speed. The maximum value of tensile strength and hardness of the weld is needed to obtain a quality weld in order to ensure that the weld is able to sustain higher loading, especially during working conditions such as those for bridge application.

\section{ACKNOWLEDGEMENTS}

The authors would like to thank the Faculty of Engineering at Universiti Putra Malaysia (UPM) and UNIKL-MFI for their support. The first author is grateful for the assistance of Dr. Azmah Hanim Mohamed Ariff (UPM) and Mr. Zainal Abidin Shah (UNIKLMFI). 


\section{REFERENCES}

American Society for Testing and Materials, A. (Vol. E 8M - 03, pp. 1-3). Structural welding code-steel (2004).

Charde, N. (2012a). Characterization of spot weld growth on dissimilar joints with different thicknesses. Journal of Mechanical Engineering and Sciences, 2, 172180.

Charde, N. (2012b). Effects of electrode deformation of resistance spot welding on 304 austenitic stainless steel weld geometry. Journal of Mechanical Engineering and Sciences, 3, 261-270.

Charde, N. (2013). Microstructure and fatigue properties of dissimilar spot welds joints of aisi 304 and aisi 1008. International Journal of Automotive and Mechanical Engineering, 7, 882-899.

Greyjevo, O. G. T. V. Z., \& Metodo, A. I. T. (2009). Optimization of weld bead geometry in tig welding process using grey relation analysis and taguchi method. Materiali in tehnologije, 43(3), 143-149.

Kukiełka, L. (1989). Designating the field areas for the contact of a rotary burnishing element with the rough surface of a part, providing a high-quality product. Journal of Mechanical Working Technology, 19, 319-356.

Lopez-Juarez, I., Rios-Cabrera, R., \& Davila-Rios, I. (2010). Implementation of an intelligent robotized gmaw welding cell, part 2: Intuitive visual programming tool for trajectory learning.

Manning, R., Ewing, J. (2009). .RACQ Vehicles Technologies. (2009). Temperatures in cars survey. RACQ Vehicles Technologies, 1-21.

Rafiqul, M. I., Ishak, M., \& Rahman, M. M. (2012). Effects of heat input on mechanical properties of metal inert gas welded $1.6 \mathrm{~mm}$ thick galvanized steel sheet. IOP Conference Series: Materials Science and Engineering, 36(1).

Rahman, M. M., Arrifin, A. K., Nor, M. J. M., \& Abdullah, S. (2008). Fatigue analysis of spot-welded joint for automative structures. SDHM Structural Durability and Health Monitoring, 4(3), 173-180.

Rahman, M. M., Bakar, R. A., Noor, M. M., Rejab, M. R. M., \& Sani, M. S. M. (2008). Fatigue life prediction of spot-welded structures: A finite element analysis approach European Journal of Scientific Research (Vol. 22, pp. 444-456).

Rahman, M. M., Rosli, A. B., Noor, M. M., Sani, M. S. M., \& Julie, J. M. (2009). Effects of spot diameter and sheets thickness on fatigue life of spot welded structure based on fea approach. American Journal of Applied Sciences, 6(1), 137-142.

Shah, L. H., Akhtar, Z., \& Ishak, M. (2013). Investigation of aluminum-stainless steel dissimilar weld quality using different filler metals. International Journal of Automotive and Mechanical Engineering, 8, 1121-1131.

Yang, W. H., \& Tarng, Y. S. (1989). Design optimization of cutting parameters for turning operations based on the taguchi method. Journal Material Processing Technology, 84, 122-129. 